\title{
Improvement of Accounting Experiment Teaching in Independent College under the Background of "Internet Plus"
}

\author{
Sijin Li, Jing Cao, Haiqing Xu \\ School of Accountancy, Dianchi College of Yunnan University, Kunming, Yunnan, 650228, China
}

Keywords: Internet Plus; Independent college; Accounting experiment teaching

\begin{abstract}
With the rapid development of the society, the Internet has become the most important infrastructure widely used, and the new technology has been combined to create endless innovation with the help of the Internet. In the teaching in independent colleges, the accounting experiment teaching is constantly improving in order to meet the needs of the times for accounting talents. In the accounting experiment teaching, the Internet technology can also be introduced into the teaching link. By means of the transmission and application of the network knowledge and information, the experimental teaching mechanism can be perfected and the teaching method can be innovated. Moreover, it can expand the teaching content and improve the teaching method, so that the accounting experiment teaching can play its part.
\end{abstract}

\section{Introduction}

In order to adapt to the current trend of social development, the ways and means of undergraduate education in independent colleges are also facing challenges. The traditional teaching mode has been difficult to meet the needs of the current society for application-oriented and innovative talents. How to adapt to the needs of the social development and cultivate the talents needed by the society is a problem that many independent colleges need to think about in the development ${ }^{[1]}$. In the major settings of Chinese independent colleges, most independent of them have an accounting major. And the number of students majoring in accounting is more, almost one thirds of the number of students in the whole school. Therefore, the education and training of accounting major students in independent colleges have a long way to go, and should be in line with the needs of accounting talents of the society and not deviate from the actual needs of social development.

\section{The Development Trend of Accounting Experiment Teaching in Independent Colleges}

\subsection{The scale of accounting experiment teaching is enlarged and the teaching curriculum is more and more perfect}

In the course of accounting experiment teaching, it is of great significance to establish a scientific and reasonable accounting experimental course system for the reform of accounting experiment teaching in modern colleges. In order to perfect the accounting experiment course system, the accounting experiment course should be integrated into the teaching plan of many subjects, so that all the subjects studied by the accounting students can cooperate with each other and divide the work reasonably. For accounting majors, whether the structure of accounting experiment curriculum is reasonable or not is directly related to the achievement of classroom learning and the efficiency of personnel training. With the improvement of the accounting experimental teaching system, the professional teaching curriculum is becoming more and more perfect to meet the needs of the society. In the accounting experiment teaching, the curriculum system is mainly set out from four aspects. First, use the experience level accounting experiment to perfect the curriculum experience. By means of experiential accounting experiment teaching, the students can understand the working nature and working environment of accounting, and stimulate the students' learning potential and motivation of accounting theory knowledge. Second, perfect the 
course system with the verification level accounting experiment ${ }^{[2]}$. In this stage, teachers should guide students to learn the traditional accounting methods and specific procedures, so that students can master the knowledge of accounting theory in the experiment. Third, we should use the comprehensive level of accounting experiments to improve the curriculum system. In the comprehensive experiment, the students of accounting major can learn the knowledge of financial accounting, management accounting, cost management and computer operation, so as to train the students' ability of analyzing and solving problems. Fourth, improve the curriculum system with innovative level accounting experiment. Innovative accounting experiments are designed to simulate the accounting environment, focusing on the cultivation of students' independent thinking ability.

\subsection{Further improvement of the team of double qualified teachers and further innovation of teaching contents}

In the accounting experiment teaching, the teacher's professional quality level has direct influence on the realization of the teaching effect. In order to promote the effect of accounting experiment teaching and train people to meet the needs of the society, the overall level of teachers in independent colleges should be improved simultaneously. At present, in order to meet the needs of the development of teaching, the teachers of independent colleges are based on the construction of double qualified teaching team, which can enhance the professional and technical ability of teachers at the same time. In this way, teachers can integrate their professional experience into classroom teaching, so as to improve the social adaptation effect of accounting experiment teaching. At the same time, the independent colleges and universities also pay attention to the education and training of the teachers, especially to the teachers with high teaching quality, so as to perfect the construction of the high quality teachers. In order to maintain the stability of teachers, we can improve teachers' teaching enthusiasm by establishing perfect incentive mechanism, welfare treatment, professional title evaluation and so on. At the same time, the content of accounting experiment teaching is constantly innovating, which influences teachers' teaching behavior and students' interest in learning. In today's changing social and economic environment, the development of social economy puts forward a lot of new requirements for accountants. If the teacher still explains the traditional accounting statistics and accounting methods according to the traditional teaching materials, the professional ability formed by the students in school learning is not enough to meet the needs of the industry ${ }^{[3]}$.

\subsection{The communication and cooperation among schools are gradually strengthened, and the teaching mode of the cooperation between production, teaching and research is being popularized}

The exchange and cooperation among schools has a positive effect on promoting the quality and level of accounting experiment teaching in schools. The school can gain more experience in the mutual exchange, and can learn from the experience of the accounting experimental teaching materials to make the teaching materials more unified and standardized. The cooperative education of production, teaching and research is an efficient training mode for talents. In this mode, the resources of industry, schools and research institutions are fully mobilized and utilized to train students' learning ability in the way of combining theoretical learning, practical operation and scientific research. It can fully train students' learning ability, application ability, operation ability and research ability, and truly realize the combination of theoretical study and practical operation, so as to cultivate high-level talents with strong adaptability. In view of the demands of accounting talents in the current economic environment, the combination of school and society can be realized through the establishment of a joint mechanism between schools and enterprises to train accounting professionals. This kind of talent training teaching mode in independent colleges is also gradually promoting. More cooperation between schools and enterprises are in the establishment of the listing. 


\section{Suggestions for Improvement of Accounting Experiment Teaching in Independent Colleges under the Background of "Internet Plus"}

\subsection{To perfect the teaching mechanism of accounting experiment teaching}

With the development of the network era, we should perfect the accounting experiment teaching mechanism and have a set of comprehensive teaching mechanism setup mode. The teaching mechanism of accounting experiment should be embodied in teaching plan, teaching management and teaching method. First of all, it is necessary to integrate the accounting experiment course into the accounting professional teaching plan, arrange the necessary credit for the accounting experiment course, ensure the accounting experiment teaching time and let the accounting experiment study get the approval of the students. Secondly, we should strengthen the establishment of accounting experiment teaching system, and provide guarantee for the development of teaching activities. For example, we should establish the fund management system of accounting experiment teaching, and clarify the source of accounting experiment teaching funds. We should establish the management system of accounting experiment teaching methods, strengthen the evaluation of accounting experiment teaching methods and the management of accounting experiment teaching activities, so that to let the accounting experiment teaching methods meet the requirements of the accounting professional teaching plan and syllabus. We should evaluate the teachers' accounting experiment teaching from the aspects of the students' learning ability and the reasonable arrangement of the teacher's teaching plan, so as to make the accounting experiment teaching develop in the direction of standardization and systematization. Only then can we promote the progress of accounting experiment teaching in independent colleges and universities ${ }^{[4]}$.

\subsection{Innovate the teaching mode of accounting experiment teaching}

In the Internet platform, teachers can use the network to demonstrate online teaching, solve questions and questions for students on the network, and students can log on to the website at any time for autonomous learning. Through the construction of the network platform of accounting experiment teaching, the combination of teaching display and network, we combine theory and practice effectively with the transfer and feedback of knowledge over the Internet. This not only facilitates teachers' online knowledge transmission, but also enhances students' ability of autonomous learning and strengthens students' ability to analyze and solve problems. In this way, the "teaching and learning" of the traditional teaching mode is transformed into "learning and thinking". Among the 10 independent colleges surveyed, 100 students majoring in accounting were selected from each college to investigate whether it is necessary to introduce the network into the accounting experiment teaching. The vast majority of students consider it necessary to introduce. It can be seen that the expectation of accounting network experiment teaching is high, and independent colleges can try to carry out it.

\subsection{Extending the teaching content of accounting experiment teaching}

In order to improve the teaching content of accounting experiment teaching, independent colleges should set up a teaching network platform with the help of the Internet to realize the sharing of network teaching data in the campus. In order to unify and standardize the requirements of experiment teaching, the professional teachers input the contents of experiment teaching into the platform, and let the students obtain the data of the platform first, and then experience and learn in the classroom. This kind of innovation mode of teaching content should be combined with accounting majority's own characteristics, knowledge content, experiment teaching task and goal and so on ${ }^{[5]}$. Moreover, it should combine the actual situation of accounting business and make use of the network platform of the school to integrate and optimize the experiment teaching contents of basic accounting, financial accounting and cost accounting, so as to improve the systematization of teaching contents. 


\subsection{Teaching method for improving accounting experiment teaching}

In order to cope with the innovation of teaching mode and content, the teaching methods of accounting experiment teaching should be changed, and different methods should be adopted for different accounting experiments. If it is an experiential accounting experiment, we can use the Internet platform to introduce professional knowledge, adopt the teaching methods of teachers' explanation and students' thinking, and assist multimedia teaching means to carry out experiment teaching. At the same time, we can also organize students to conduct field research to enable students to experience and summarize the needs of accounting knowledge in practice. For confirmatory accounting experiments, we can use the Internet platform to explain the experimental methods of student exercises after class.

\section{Conclusions}

The reform of accounting experiment teaching in independent colleges can use the background platform of "Internet Plus" to share and transmit the information of the network to the teaching process. In this way, it not only facilitates the unification and coordination of the teacher's curriculum, but also stimulates students' autonomous learning, and also provides effective teaching to meet the needs of social talents. Therefore, it is imperative to reform the accounting experiment teaching. Independent colleges should innovate the teaching mode, method, content and mechanism of the accounting experiment teaching, so that to new teaching ideas and tools to cultivate the social needs of accounting professionals.

\section{References}

[1] Zhao Gailing. Reform and Innovation of Accounting Experiment Teaching Model [J]. Friends of Accountants (Early Issue), 2010, (07), 45-48.

[2] Xie Lei, Cui Yan. Analysis on the Development Trend of Accounting Experiment Teaching in the New Period [J]. Industry and Science and Technology Forum, 2012, (04), 99-100.

[3] Tu Haiyin. A Study on the Reform of Accounting Experiment Teaching System from the Perspective of Learner [J]. Accounting Bulletin, 2014, (22), 8-11.

[4] Wang Chun, Wang Yang. Research on the Reform of Accounting Experiment Teaching Mode in Local Colleges [J]. North Economy and Trade, 2015, (09), 234-235.

[5] Yang Ruiping, Wu Qiusheng, Wang Xiaoliang. A Study on the Reform of Financial Accounting Experiment Teaching under the Background of "Moulding Course"[J]. Monthly Journal of Accounting, 2016, (36), 109-113. 